\title{
Systematic relationships and cospeciation of bacterial endosymbionts and their carpenter ant host species: proposal of the new taxon Candidatus Blochmannia gen. nov.
}

\author{
Christina Sauer, ${ }^{1,2}$ Erko Stackebrandt, ${ }^{3}$ Jürgen Gadau, ${ }^{2}$ Bert Hölldobler ${ }^{2}$ \\ and Roy Gross ${ }^{1}$
}

Author for correspondence: Roy Gross. Tel: +49931 888 4403. Fax: +499318884402. e-mail: roy@biozentrum.uni-wuerzburg.de

1,2 Lehrstuhl für Mikrobiologie1, Lehrstuh für Verhaltensphysiologie und Soziobiologie², Theodor-Boveri-Institut, Biozentrum der Universität Würzburg, Am Hubland, D-97074 Würzburg, Germany

3 DSMZ, Deutsche Sammlung für

Mikroorganismen und Zellkulturen $\mathrm{GmbH}$, Mascheroder Weg 1b, D-38124 Braunschweig, Germany
The systematic relationships of intracellular bacteria of 13 Camponotus species (carpenter ants) from America and Europe were compared to those of their hosts. Phylogenetic trees of the bacteria and the ants were based on 16S rDNA (rrs) gene sequences and mitochondrial cytochrome oxidase subunit I (COI) gene sequences, respectively. The bacterial endosymbionts of Camponotus spp. form a distinct lineage in the $\gamma$-subclass of the Proteobacteria. The taxa most closely related to these bacteria are endosymbionts of aphids and the tsetse fly. The bacterial and host phylogenies deduced from the sequence data show a high degree of congruence, providing significant evidence for cospeciation of the bacteria and the ants and a maternal transmission route of the symbionts. The cloned rrs genes of the endosymbionts contain putative intervening sequences (IVSs) with a much lower $G+C$ content than the mean of the respective rrs genes. By in situ hybridization specific 165 rDNA oligonucleotide probes verified the presence of the bacteria within tissues of three of the eukaryotic hosts. It is proposed that the endosymbionts of these three carpenter ants be assigned to a new taxon 'Candidatus Blochmannia gen. nov.' with the symbionts of the individual ants being species named according to their host, ' Candidatus Blochmannia floridanus sp. nov.', ' Candidatus Blochmannia herculeanus sp. nov.' and 'Candidatus Blochmannia rufipes sp. nov.'.

Keywords: 16S rDNA, endosymbiosis, Camponotus spp., 'Candidatus Blochmannia', cytochrome oxidase subunit I

\section{INTRODUCTION}

Symbioses between bacteria and insects are very widespread and frequently found in the orders $\mathrm{Co}$ leoptera, Blattaria, Homoptera and Hymenoptera (Buchner, 1965; Dasch et al., 1984; Douglas, 1989). In many cases these interspecies interactions are thought to be obligate and mutualistic. In fact, highly developed symbiotic systems are found in insects spe-

\footnotetext{
Abbreviations: COI, cytochrome oxidase subunit I; IVS, intervening sequence.

The GenBank accession numbers for the partial cytochrome oxidase subunit I sequences reported in this paper are AF187954-AF187962.
}

cializing on unbalanced diets such as plant sap or mammalian blood. The best characterized examples for such interactions are the intracellular endosymbionts of aphids (Buchnera aphidicola), tsetse flies (Wigglesworthia glossinidia), weevils and cockroaches (Aksoy, 1995; Baumann et al., 1995; Bandi et al., 1995; Heddi et al., 1999). In all of these symbiotic interactions the micro-organisms appear to be involved in metabolic processes, e.g. provision with essential amino acids and vitamins or recycling of uric acid nitrogen for their host organisms (Baumann et al., 1995; Cochran, 1985; Douglas, 1998; Heddi et al., 1999; Nogge, 1982). Inside the body of their host species such symbiotic bacteria are resident within specialized host cells, the mycetocytes, which can form 
symbiotic organs, so-called mycetomes. Alternatively, the bacteria-containing mycetocytes can be intercalated between regular enterocytes of the mid-gut epithelium. In agreement with the intimate association of the bacteria and their host, the micro-organisms generally cannot be cultivated outside the host tissues and the host organism usually suffers when they lose their symbionts (Baumann \& Moran, 1997).

Essential symbiotic bacteria appear to be transmitted maternally, although in most cases the actual transmission pathway is not known. The fossil records of aphids suggest a very ancient coexistence of aphids with Buchnera, probably dating back to 160-250 million years (Baumann et al., 1997; Lambert \& Moran, 1998; Moran et al., 1993). In agreement with this long-lasting association and with a vertical transmission route, the comparison of the phylogeny of the symbiotic bacteria and their host animals revealed a strictly congruent evolution (Baumann et al., 1997; Moran et al., 1993). A similar evolutionary relationship was recently described for tsetse flies and cockroaches with their respective intracellular symbiotic bacteria (Bandi et al., 1995; Chen et al., 1999). Other intracellular bacteria, for instance those belonging to the parasitic Wolbachia group, do not show cospeciation with their hosts indicating that horizontal exchanges have occurred (O'Neill et al., 1992).

In 1887 Blochmann described a close association of 'bacteria-like structures' with the tissues of the midgut and the ovaries of the ant species Camponotus ligniperdus (formerly Camponotus ligniperda; Bolton 1996) and Formica fusca which both belong to the subfamily Formicinae (Blochmann, 1887). These bacteria are Gram-negative rods of variable length, large numbers of which reside in the cytoplasm of mycetocytes intercalated between normal epithelial cells (Dasch et al., 1984; Schröder et al., 1996). The same bacteria are also found in the cytoplasm of oocytes of queens and workers, which suggests a transovarial transmission route of the bacteria (Buchner, 1965; Kolb, 1959; Schröder et al., 1996).

The recent comparison of the $16 \mathrm{~S}$ rDNA sequences of the endosymbionts of four different Camponotus species revealed that they were most closely related to each other forming a distinct taxonomic group within the $\gamma$-subclass of Proteobacteria (Schröder et al., 1996). The most closely related taxa are symbionts of the tsetse fly and of the aphids (Aksoy, 1995; Baumann et al., 1995; Schröder et al., 1996). The differences within the 16S rDNA sequences of the four Camponotus symbionts isolated from two European and two American ant species correlated with the geographical distribution of their host animals; this suggested the possibility of a concordant evolution of the ant symbionts and their host species (Schröder et al., 1996). In the present study we extended this analysis and investigated the systematic relationships and phylogeny of the symbionts of 13 Camponotus species isolated from Europe and America. In addition, partial mitochondrial cytochrome oxidase subunit I (COI) gene sequences of their host species were determined, allowing the comparison of the molecular phylogeny of both the symbionts and their host species. The phylogenetic trees obtained for the bacterial endosymbionts as well as for their host species suggests a highly synchronous cospeciation process of both partners.

\section{METHODS}

Ants, bacterial strains and growth conditions. The origin of the ant species used in this study is presented in Table 1 . The ants were cultivated at $25^{\circ} \mathrm{C}$ with $50 \%$ humidity in plastic boxes providing artificial nests. They were fed with honey water and cockroach pieces (Nauphoeta cinera) twice a week. For cloning experiments the Escherichia coli strain DH5 $\alpha$ (Pharmacia) was used and grown in Luria-Bertani (LB) broth (Gibco). If required, ampicillin was added at a final concentration of $50 \mu \mathrm{g} \mathrm{ml}^{-1}$.

Characterization of the rrs genes of the endosymbionts. DNA cleavage with restriction enzymes, PCR, DNA ligation, preparation of plasmid DNA, gel electrophoresis on agarose gels and transformation of $E$. coli DH5 $\alpha$ was performed according to standard procedures (Sambrook et al., 1989). DNA sequencing was carried out on an ABI PRISM 377 (PE Applied Biosystems) automatic sequencer according to the manufacturer's protocol. As templates for the PCR reactions, crushed mid-gut preparations of the ant species shown in Table 1 were used. The rrs genes of the endosymbionts were selectively amplified using the previously described primers SL (5'-TTGGGATCCAGAGTTTGATCATGGCTCAGAT-3') and SR (5'-CACGAATTCTACCTTGTTACGACTTCACCCC-3') (Schröder et al., 1996). The primer sequences contain restriction enzyme cleavage sites for cloning experiments and are complementary to conserved regions characteristic for eubacterial rrs genes (Amann et al., 1991, 1995). The PCR reactions were performed in a total volume of $100 \mu$ containing $0.2 \mathrm{mM}$ dNTPs, $1 \mathrm{mM} \mathrm{MgCl}$, 70 pmol each oligonucleotide and 2.5 U Taq DNA polymerase (Promega). Amplification was performed in a Bio-Med 60 thermocycler with the following conditions : 30 s denaturation at $94^{\circ} \mathrm{C}, 30$ s primer annealing at $55^{\circ} \mathrm{C}$ and $3 \mathrm{~min}$ primer extension at $72^{\circ} \mathrm{C}$. Generally 40 PCR cycles were run. The amplified DNA fragments were purified using a QIAquick PCR Purification Kit (Qiagen) and ligated into pUC18 (Pharmacia).

Genetic linkage of the $16 \mathrm{~S}$ and $23 \mathrm{~S}$ genes in the rDNA operons of the endosymbiotic bacteria shown in Table 1 was investigated by PCR amplification of the intervening DNA segment between these two genes as described previously (Aksoy, 1995; Aksoy et al., 1997). Control PCR reactions were performed in parallel using primers specific for the $r r s$ genes of the endosymbionts (camp.L, 5'-GAATTACTGGGCGTAAAGAGT-3'; camp.R, 5'-GGAACGTATTCACCGTGAC-3') (Schröder et al., 1996).

Sequencing of partial mitochondrial $\mathrm{COI}$ of the ant species. DNA of individual ants was isolated using a CTAB-phenol extraction method (Hunt \& Page, 1994). Part of the mitochondrial COI gene was amplified using the primers provided by Ted Schultz, Smithsonian Institution (unpublished data; for primer sequences see Gadau et al., 1999). PCR reactions were performed in a total volume of $25 \mu 1$ containing $0.2 \mathrm{mM}$ dNTPs, $1 \mathrm{mM} \mathrm{MgCl}_{2}, 70 \mathrm{pmol}$ each 
Table 1. Ant species, their geographical location and GenBank accession numbers for the $16 \mathrm{~S}$ rDNA and partial COI sequences

\begin{tabular}{|c|c|c|c|}
\hline Species (subgenus) & Geographical origin & $\begin{array}{c}\text { Accession no. } \\
\text { (16S rDNA) }\end{array}$ & $\begin{array}{l}\text { Accession no. } \\
\quad(\text { COI) }\end{array}$ \\
\hline Camponotus (Myrmothrix) atriceps & Trinidad & AJ245591 & AF186361 \\
\hline Camponotus (Tanaemyrmex) balzani & Madre de Dios, Peru & AJ245596 & AF187955 \\
\hline Camponotus (Tanaemyrmex) castaneus & Bayhead, Florida, USA & AJ245594 & AF187959 \\
\hline Camponotus (Myrmothrix) floridanus & Ft Pierce, Florida, USA & X92549 & AF186362 \\
\hline Camponotus (Camponotus) herculeanus (E)* & Bavaria, Germany & X92550 & AF176687 \\
\hline Camponotus (Camponotus) herculeanus (A)* & Idaho, USA & AJ 250715 & $\begin{array}{l}\text { Sequence identical } \\
\text { to AF176687 }\end{array}$ \\
\hline Camponotus (Camponotus) ligniperdus & Leinach, Germany & X92551 & AF176686 \\
\hline Camponotus (Camponotus) pennsylvanicus & USA & AJ245598 & AF189360 \\
\hline Camponotus (Myrmothrix) rufipes & Rio, Brazil & X92552 & AF187957 \\
\hline Camponotus (Myrmothrix) rufipes B & El Bagual, Argentina & AJ245597 & AF187956 \\
\hline Camponotus (Myrmepomis) sericeiventris & Missiones, Argentina & AJ245593 & AF187960 \\
\hline Camponotus (Tanaemyrmex) silvicola & Cuzco Amazonico, Peru & AJ245592 & AF187954 \\
\hline Camponotus (Tanaemyrmex) socius & Florida, USA & AJ245595 & AF187958 \\
\hline
\end{tabular}

* Camponotus herculeanus was isolated in Europe (E) and in the USA (A).

oligonucleotide and 2.5 U Taq polymerase (Promega). The samples were amplified in a Bio-Med 60 Thermocycler and the conditions used for thermal cycling were as follows: denaturation of the target DNA at $94^{\circ} \mathrm{C}$ for 3 min, followed by 35 cycles consisting of 1 min denaturation at $94^{\circ} \mathrm{C}, 30 \mathrm{~s}$ primer annealing at $47^{\circ} \mathrm{C}$ and $1 \mathrm{~min} 30 \mathrm{~s}$ extension at $72^{\circ} \mathrm{C}$. At the end of the cycles, the reaction mixture was kept at $72{ }^{\circ} \mathrm{C}$ for $5 \mathrm{~min}$. PCR products were purified using microcon 100 microconcentrators (Amicon), followed by automated sequencing of double-stranded products (Big Dye-kit; Perkin Elmer). We sequenced from both directions and all sequences were unambiguously aligned by eye.

In situ hybridization. The oligonucleotides used for in situ hybridization were described previously (Schröder et al., 1996). They were enzymically labelled with digoxigenin-11ddUTP by terminal transferase (Boehringer Mannheim) following the manufacturer's instructions. Mid-gut cryosections were fixed in $4 \%(\mathrm{w} / \mathrm{v})$ paraformaldehyde dissolved in PBS buffer, $\mathrm{pH} 7 \cdot 2$, for $30 \mathrm{~min}$ at $4{ }^{\circ} \mathrm{C}$. Then they were rinsed in PBS, incubated for 15 min with $0.5 \mu \mathrm{g}$ proteinase $\mathrm{K} \mathrm{ml}^{-1}$, rinsed and fixed once more as described above. Hybridization was carried out overnight with $60 \mathrm{ng}$ labelled oligonucleotide in $20 \mu \mathrm{l} 5 \times$ SET hybridization buffer [ $5 \times$ SET: $0.75 \mathrm{M} \mathrm{NaCl}, 5 \mathrm{mM}$ EDTA, $0.1 \mathrm{M}$ Tris, $0.2 \%$ blocking reagent (Boehringer Mannheim), $0.025 \%$ SDS] at $42{ }^{\circ} \mathrm{C}$ in the case of the hercu 2 oligonucleotides and at $37^{\circ} \mathrm{C}$ for the flori3 and rufi2 oligonucleotides. The slides were washed for $15 \mathrm{~min}$ in $0 \cdot 2 \times$ SET at room temperature: non-specific binding was blocked by covering the slides with a solution containing $100 \mathrm{mM}$ maleic acid, $150 \mathrm{mM} \mathrm{NaCl}, 0.5 \%$ blocking reagent for $30 \mathrm{~min}$. The slides were then incubated with alkaline-phosphatase-conjugated Fab fragment specific for the digoxigenin moiety (Boehringer Mannheim). Unbound $\mathrm{Fab}$ fragments were removed by washing with a solution containing $100 \mathrm{mM}$ Tris/ $\mathrm{HCl}, 100 \mathrm{mM} \mathrm{NaCl}$, $50 \mathrm{mM} \mathrm{MgCl} 2, \mathrm{pH} 9 \cdot 5$. Alkaline phosphatase activity was visualized by the formation of a darkly coloured insoluble precipitate. As a substrate, a 1:50 dilution of the nitro blue tetrazolium/bromo-4-chloro-3-indolylphosphate stock solution (Boehringer Mannheim) in a solution containing
$100 \mathrm{mM}$ Tris/ $\mathrm{HCl}, 100 \mathrm{mM} \mathrm{NaCl}, 50 \mathrm{mM} \mathrm{MgCl}_{2}, \mathrm{pH} 9 \cdot 5$, was used.

Phylogenetic analysis. 16S rDNA sequences of the endosymbiotic bacteria were compared with the 16S DNA database of members of the $\gamma$-subclass of Proteobacteria which are deposited in the ribosomal database project (RDP) (Maidak et al., 1997). Similarity values were transformed into phylogenetic distance values that compensate for multiple substitutions at any given site in the sequence (Jukes \& Cantor, 1969). The least square distance method of De Soete (1983), as well as the programs Neighbour-joining and Maximum-likelihood contained in the PHYLIP program package (Felsenstein, 1993; Saitou \& Nei, 1987), were used for construction of phylogenetic dendrograms. The default settings of the program DNAML version 3.5c (transition/ transversion rate $2 \cdot 0$; use of empirical base frequencies) were used for maximum-likelihood analysis (Felsenstein, 1993). For calculation of bootstrap values, 500 trees were analysed using the programs NJFIND and NJBOOT. The program PAUP 4.0 (Swofford, 1998) was used for the phylogenetic analysis of the mitochondrial COI DNA sequences.

\section{RESULTS}

\section{Characterization of the 16S rDNA sequences of endosymbiotic bacteria of Camponotus species}

The $r r s$ genes encoding the 16S RNA of endosymbiotic bacteria from nine Camponotus species were amplified and analysed in addition to the four previously described rrs sequences (Schröder et al., 1996) (Table 1). In all but three cases (Camponotus atriceps, Camponotus sericeiventris and Camponotus pennsylvanicus) almost the entire rrs gene DNA sequences were analysed corresponding to about $96 \%$ of the E. coli rrs sequence. The shorter sequences contained between 1270 and $1320 \mathrm{nt}$. The comparison of the sequences with the 16S DNA sequences deposited in the RDP revealed that all of the endosymbionts are more closely 


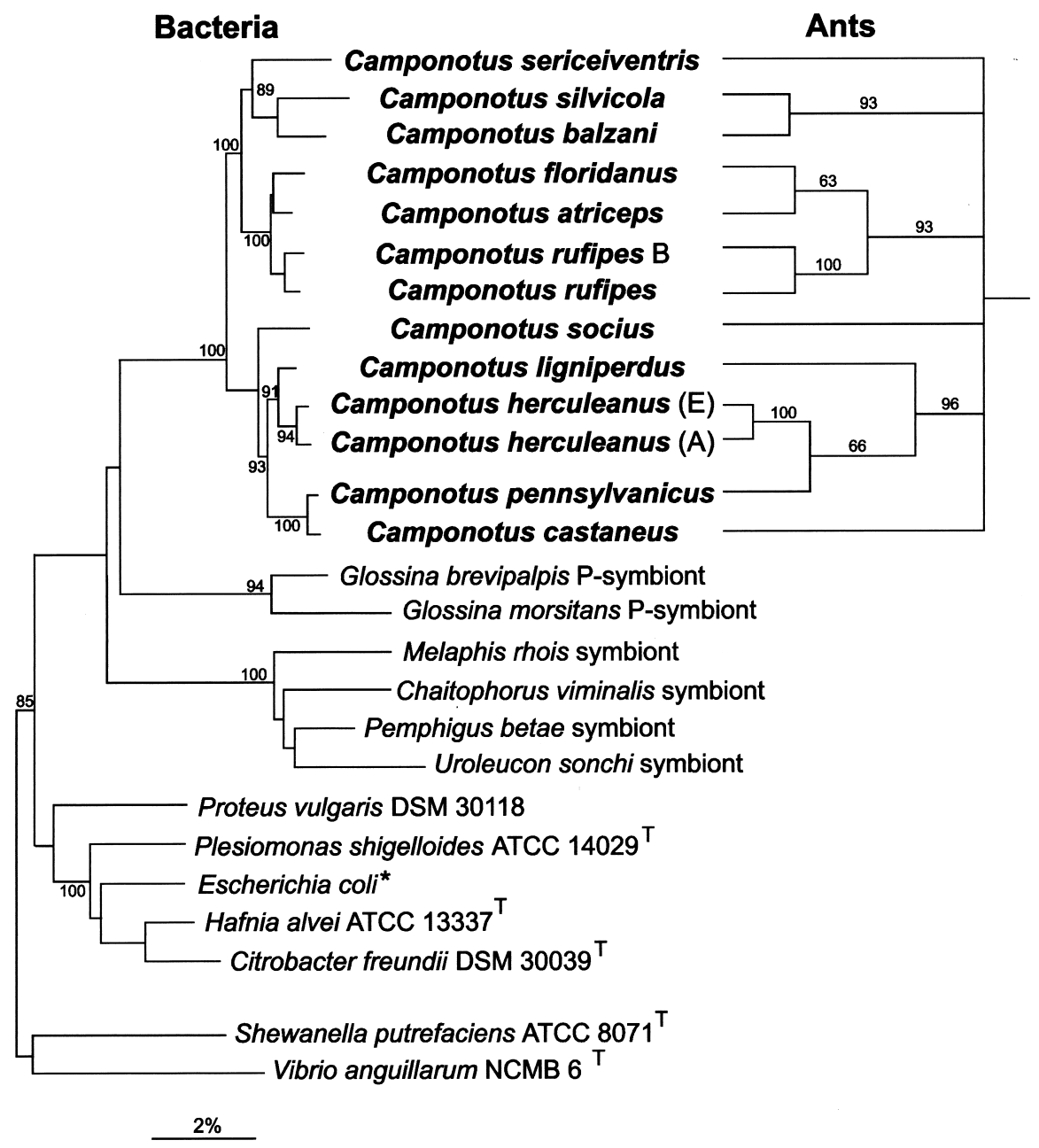

Fig. 1. Comparison of the phylogenetic trees of the endosymbionts of Camponotus species and their host organisms. The phylogenetic tree of the endosymbionts is based on their 16S rDNA sequences and was calculated according to De Soete (1983), whereas the tree of their host species is based on COI sequences calculated using the PAUP 4.0 program (Swofford, 1998). The bar represents $2 \%$ difference in the corrected sequences (Jukes \& Cantor, 1969), as determined by measuring the length of the horizontal lines connecting two species. Numbers refer to bootstrap values of calculated 500 trees. For comparison, two primary endosymbionts of two tsetse fly species, four primary symbionts of aphids and several members of the Enterobacteriaceae are shown. The EMBL accession numbers of the $16 \mathrm{~S}$ rDNA sequences used for this analysis are as follows: Proteus vulgaris, X07652; Plesiomonas shigelloides, M59159; E. coli, V00333; Hafnia alvei, M59155; Citrobacter freundii, AJ233408; Shewanella putrefaciens, X82133; Vibrio anguillarum, X16895; P-symbionts of Glossina brevipalpis, L37341; Glossina morsitans, L37339; Melaphis rhois, M63255; Chaitophorus viminalis, M63252; Pemphigus betae, M63254; Uroleucon sonchi, M63250.

related to each other than to any other bacterial species. In agreement with previous results, all of the symbionts are members of the $\gamma$-subclass of the Proteobacteria, where they form a new taxon which shows between about 10 and $14 \%$ divergence from the most closely related taxa, namely the endosymbionts of tsetse flies and those of aphids. Together these three taxonomic groups form a cluster of endosymbiotic bacteria, which is placed adjacent to members of the family Enterobacteriaceae (Fig. 1).

With the different tree algorithms used, identical phylogenetic branching patterns were obtained (Fig. 1). Within the Camponotus symbionts three subclusters are apparent, in which the strains are more related to each other than to the members of the other subclusters. The topology of this branching pattern is supported by highly significant bootstrap values $(89-100 \%)$. The first subcluster consists of the symbionts of the South American ant species Camponotus balzani (Peru) and Camponotus silvicola (Peru), sharing a similarity value of $96.8 \%$. The symbiont of C. sericeiventris (Argentina) also clusters with these two species, although it appears to be more distantly related $(95 \cdot 5-96 \cdot 2 \%$ similarity). The second group contains the symbionts of four ant species with a similarity value of 97.9-98.9\%, namely Camponotus floridanus (Florida, USA), C. atriceps (Trinidad), 


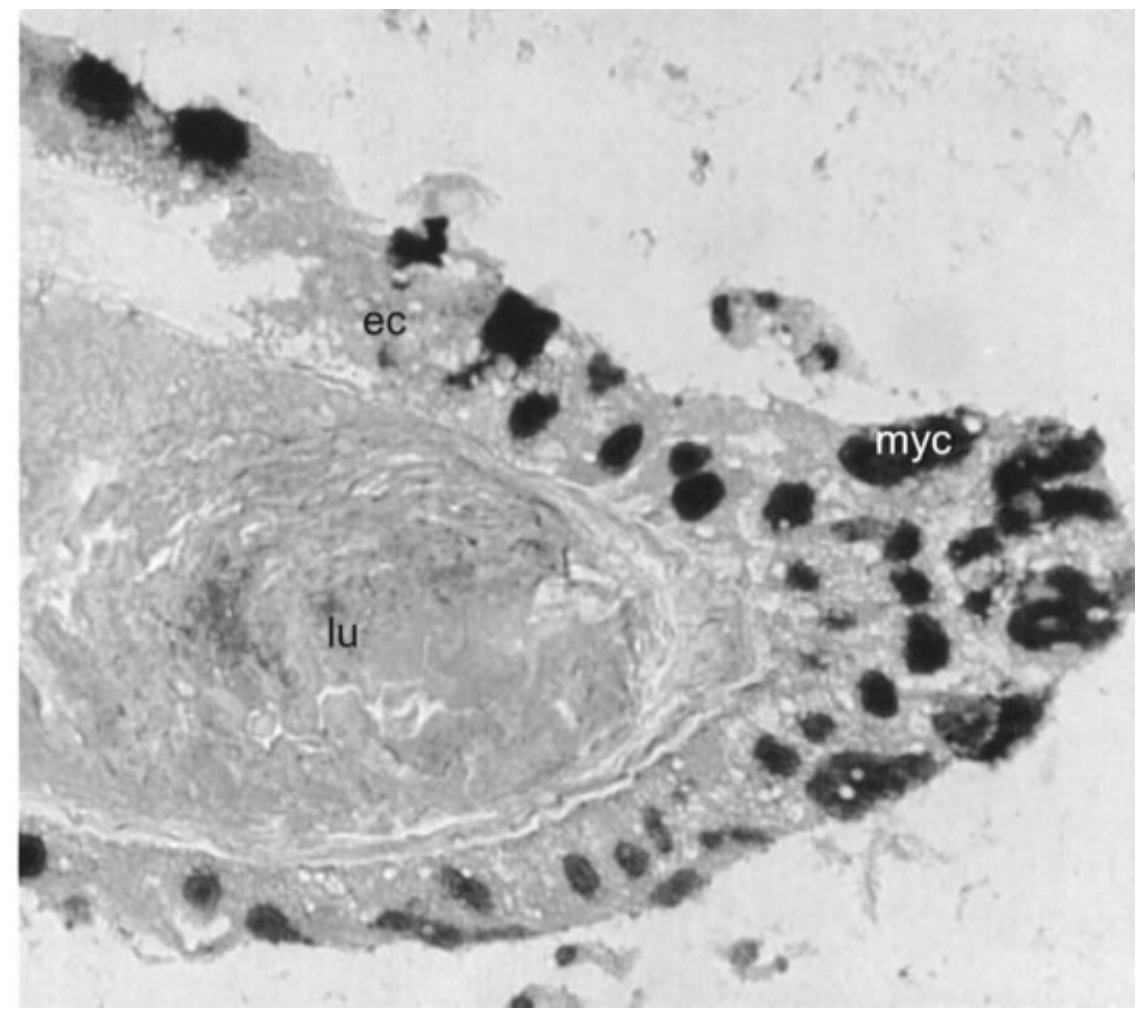

Fig. 2. In situ hybridization with oligonucleotides specific for the $C$. floridanus symbiont in a mid-gut preparation of $C$. floridanus. myc, Mycetocyte with hybridizing bacteria; ec, mid-gut epithelial cell; lu, lumen of the mid-gut with excrement.

Camponotus rufipes (Brazil) and the closely related Camponotus rufipes B (Argentina). The symbionts of the two ant species C. ligniperdus (Germany) and Camponotus herculeanus (Germany and USA) form a group together with the bacteria from two other species resident in the USA, $C$. pennsylvanicus and Camponotus castaneus, exhibiting a similarity of $98 \cdot 1-99 \cdot 7 \%$. The symbiont of Camponotus socius (Florida, USA) does not fall in any of the clades, although it appears to be more closely related to the clade containing $C$. ligniperdus, $C$. herculeanus, $C$. pennsylvanicus and $C$. castaneus (similarity of $97 \cdot 0-97 \cdot 2 \%)$ than to the other clades $(94 \cdot 3-97 \cdot 2 \%)$. Members of the first and second subcluster (no sequence information is available for the symbiont of C. sericeiventris) are characterized by 4-7 additional bases located at position 1550-1453 (E. coli sequence).

\section{In situ detection of symbionts in mid-gut preparations of several Camponotus species}

To confirm that the 16S rDNA sequences derived from the PCR reaction of mid-gut preparations of the ants indeed correspond to the symbiotic bacteria, we performed in situ hybridization experiments with three of the ant species, C. rufipes, C. ligniperdus and C. floridanus, using oligonucleotide primers specific for the respective symbionts. Fig. 2 shows a typical result obtained with a mid-gut preparation of C. floridanus and the oligonucleotide specific for its symbiont. The dark coloured cells represent the mycetocytes filled up with the symbiotic bacteria, which are intercalated between normal epithelial cells. No labelling was obtained using oligonucleotides specific for the other species (data not shown).

\section{Intervening DNA sequences (IVSs) are present in the symbiont rrs genes}

In several bacterial genera, including Campylobacter, Helicobacter and Clostridium, so-called IVSs were found representing DNA sequences present in the respective rrs genes, which are absent from the mature 16S rRNA sequences (see Rainey et al., 1996). Interestingly, the alignment of the endosymbiont $16 \mathrm{~S}$ rDNA sequences with that of e.g. E. coli also revealed the presence of putative IVSs which are located between positions 82-88/83-87 (insert I) and 207-212/208-211 (insert II) of the E. coli rrs sequence. The length of the insert I sequences ranges between 7 and $21 \mathrm{nt}$, that of insert II between 6 and 31 bases. Only 2 bp constitute insert I in C. ligniperdus and C. herculeanus symbionts. Inserts are absent in the symbionts of tsetse fly and aphid symbionts as well as in Enterobacteriaceae. As in other cases, these sequences differ in their $\mathrm{G}+\mathrm{C}$ content very much from the mean of the respective rrs 
(a)

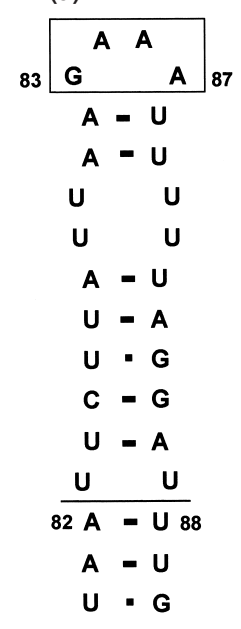

(b)

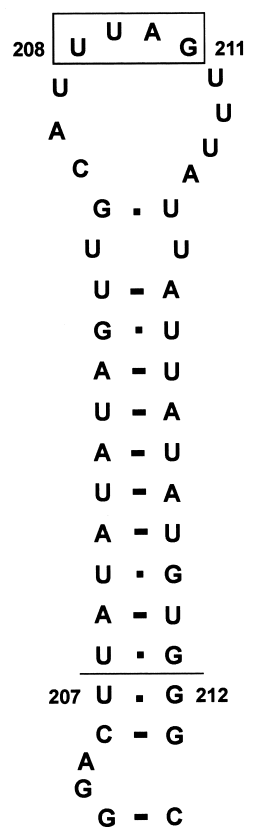

Fig. 3. Structure of the putative IVSs present in the 165 rDNA sequences of $C$. rufipes endosymbionts. Numbers refer to positions in the $E$. coli $16 \mathrm{~S}$ rDNA sequence. (a) Insert I; (b) insert II.

genes. The $\mathrm{G}+\mathrm{C}$ content of the $16 \mathrm{~S}$ rDNA of the Camponotus endosymbionts ranges between 48 and $50 \mathrm{~mol} \%$ which is in a similar range as that of tsetse fly and aphid symbionts, while that of Enterobacteriaceae is slightly higher $(53-55 \%)$. The $\mathrm{G}+\mathrm{C}$ content of the inserts ranges between 5 and $33 \%$. Only the inserts of the $C$. socius symbiont exhibit a $\mathrm{G}+\mathrm{C}$ content of $43 \mathrm{~mol} \%$. The inserts form a rather stable secondary structure. An example of the secondary structure of the inserts of the C. rufipes symbiont, which exhibits the longest inserts in both regions, are depicted in Fig. 3.

\section{Structural organization of the rDNA operons of symbiotic bacteria}

In the case of the free-living Enterobacteriaceae the rRNA genes are organized in the order $5^{\prime}-16 \mathrm{~S}-23 \mathrm{~S}-5 \mathrm{~S}-$ 3 ', forming a single transcription unit. The aphid symbionts are somewhat unusual, because their rRNA genes are organized into two transcription units (Baumann et al., 1995). In fact, in Buchnera spp. the gene encoding the 16S RNA is not located upstream of the 23S RNA gene (Rouhbakhsh \& Baumann, 1995). This is in contrast to the tsetse fly symbionts, where the $16 \mathrm{~S}$ rDNA gene is located upstream of the 23S rDNA gene (Aksoy, 1995). Using a PCR strategy we attempted to analyse the relative position of the $16 \mathrm{~S}$ rDNA in the case of the ant symbionts. As shown in Fig. 4, in the case of all 12 Camponotus symbionts tested so far, the $16 \mathrm{~S}$ rDNA apparently is not located upstream of the
23S rDNA, and the $16 \mathrm{~S}$ and $23 \mathrm{~S}$ genes seem to be organized in different transcription units like in the aphid symbionts.

\section{Characterization of the mitochondrial COI DNA sequence of several Camponotus species}

DNA fragments (385 bp) containing part of the coding region of the mitochondrial COI from 13 Camponotus species were obtained and used for a phylogenetic analysis. These data were analysed using the branchand-bound method implemented by PAUP 4.0 (Swofford, 1998). Two most parsimonious trees were found (tree length, 335; consistency index, 0.56; retention index, 0.55). Both trees differed only in the relative position of the three closely related taxa (C. ligniperdus, $C$. herculeanus and $C$. pennsylvanicus) and otherwise had the same topology. Bootstrap values based on 1000 replications are given in the strict consensus tree in Fig. 1. Clades with high bootstrap support are: (1) the Camponotus sensu stricto subgenus (C. ligniperdus, $C$. herculeanus (E), $C$. herculeanus (A) and $C$. pennsylvanicus); (2) the South American species of the subgenus Tanaemyrmex (C. silvicola and C. balzani); and (3) the North and South American species of the subgenus Myrmothrix (C. floridanus, C. atriceps, $C$. rufipes and $C$. rufipes B). C. rufipes B is not yet described as a valid species but sequence data and significant differences in certain physiological and life history features make it very likely that $C$. rufipes and C. rufipes B are in fact different species. The two North American species of the subgenus Tanaemyrmex $(C$. socius and $C$. castaneus) do not form a cluster, but Tanaemyrmex is a huge and very diverse subgenus and it is not surprising that these species do not cluster together. C. sericeiventris is, as the only member of the subgenus Myrmepomis, also part of the unresolved polytomy at the basis of the tree (Fig. 1).

\section{Comparison of the phylogenetic trees of the bacterial endosymbionts and their host organisms}

The phylogenetic tree of the endosymbionts of 13 different Camponotus species based on the 16S RNA sequences indicated the presence of at least three distinct groups, with the members of each group displaying greater similarity to each other than to the members of the other groups. Within these three groups, the symbionts of $C$. sericeiventris and $C$. socius are quite distantly related to their direct neighbours. The establishment of a phylogenetic tree of their host species based on COI DNA sequences allowed the comparison of the branching pattern of the symbiont and host animal trees. This analysis reveals a strikingly similar branching pattern in both trees (Fig. 1). The exception is $C$. castaneus, which cannot be related to any other species on the basis of the COI analysis, but its symbiont appears to be very closely related to those of $C$. pennsylvanicus and the other sensu stricto Camponotus species. Nevertheless, both trees show very significant taxonomic relationship with each other 

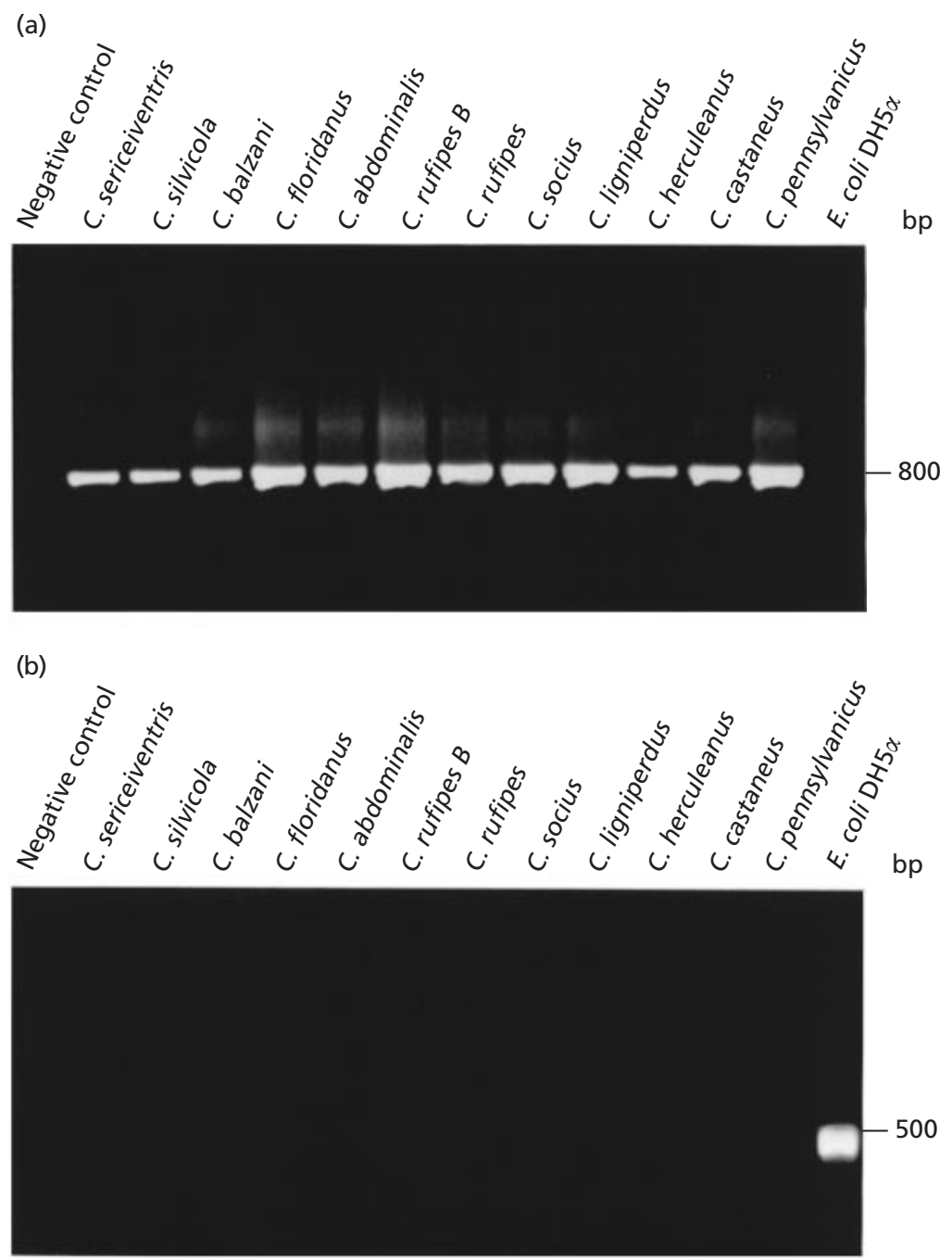

Fig. 4. (a) Agarose gel showing PCR products derived from primers specific for Camponotus symbionts binding within the respective 16S rDNA genes. (b) Agarose gel showing PCR products obtained with primers hybridizing with highly conserved regions of the $16 \mathrm{~S}$ rDNA and 235 rDNA of eubacteria.

demonstrating a congruent evolution of the symbiotic bacteria and their host species.

\section{DISCUSSION}

It is generally believed that the transmission of intracellular endosymbionts residing in mycetocytes occurs vertically (Buchner, 1965). Accordingly, the evolution of the symbiotic bacteria and their host animals should have occurred in a highly congruent fashion. Such a cospeciation of symbiotic partners has in fact been documented for several bacteria/insect associations including those of aphids, tsetse flies and cockroaches with their respective symbionts (Baumann et al., 1995; Aksoy, 1995; Bandi et al., 1995). In the case of the ant/bacteria symbiosis, the phylogenetic trees of the bacteria and their host organisms are highly congruent for 12 out of the 13 ant/bacteria relationships analysed and generally fit very well with classical systematics based mainly on morphological criteria.

The North and South American species of the subgenus Myrmothrix (C. floridanus, $C$. atriceps, $C$. rufipes and $C$. rufipes B) form a distinct cluster within both phylogenetic trees derived from the 16S rDNA and COI sequences, respectively. The same holds true for the Camponotus sensu stricto group [C. ligniperdus, $C$. herculeanus (E), C. herculeanus (A) and C. pennsylvanicus]. On the basis of classical systematics $C$. sericeiventris belongs to the subgenus Myrmepomis. In agreement with this position, the analysis of the COI sequence did not reveal a significant relationship to the other ant species analysed here. Similarly, the 16S rDNA sequence of its symbionts also demonstrates a relatively isolated position of $C$. sericeiventris, but provides first evidence for a significant relation to several South American species (C. silvicola, C. bal- 
zani) belonging to the subgenus Tanaemyrmex. The systematics of the subgenus Tanaemyrmex is complex. It is a huge and apparently quite heterogeneous subgenus which includes several species of uncertain classification. In fact, C. silvicola and C. balzani are the only species belonging to this subgenus for which a significant clustering is obvious on the basis of both the COI and the $16 \mathrm{~S}$ rDNA data presented here. The other two Tanaemyrmex species analysed here, $C$. socius and C. castaneus, are found in different clusters of the symbiont dendrograms or cannot be resolved on the basis of the COI dendrograms. In the case of C. socius, the 16S rDNA sequence of its symbiotic bacteria indicates, however, a somewhat closer relationship of C. socius with the Camponotus sensu stricto subgenus (C. ligniperdus, C. herculeanus and C. pennsylvanicus) than with other species. We expect that further molecular analysis of other members of the subgenus Tanaemyrmex will lead to a major revision of their systematic positions.

The generally high degree of congruence in the phylogenetic trees of the endosymbiotic bacteria and their host ant species strongly indicates that they have diversified in parallel and supports the maternal transmission route. Despite the congruence of the phylogenetic trees of both the symbionts and their host animals, their geographical distribution is reflected only partially in the phylogenetic trees. For example, the species $C$. floridanus is living in Florida, but is more closely related to $C$. rufipes, isolated from geographically distant regions in South America, than to other species resident in Florida, such as $C$. castaneus and $C$. socius. This indicates that long distance migrations of ants have occurred in the past and that in general no horizontal transmission of the symbionts had occurred since then despite the geographical overlap or close neighbourhood of several distinct ant species.

The geographical distribution of $C$. herculeanus is of particular interest, because this species is found in Europe, Asia and in North America. In this study we have analysed the symbionts of a European $C$. herculeanus population which clusters together with the European and American species C. ligniperdus and C. pennsylvanicus, respectively. This fact is in agreement with classical systematics which classifies these species in the Camponotus sensu stricto subgenus. Moreover, the COI sequence of $C$. herculeanus derived from an American population was recently found to be identical to the COI sequence of the European counterpart (Gadau et al., 1999) and, as shown here, the $16 \mathrm{~S}$ rDNA sequences of their symbionts show $99 \cdot 2 \%$ similarity. This suggests that $C$. herculeanus populations have been separated only recently between the two continents, possibly after the disruption of the land bridge between Alaska and Asia at the end of the last ice age about 8000 years ago.

The only exception to this pattern of congruent evolution appears to be $C$. castaneus. Among the 13 species analysed it is the only one for which no congruence of the symbiont and COI based dendrograms is obvious. In fact, the close relationship of $C$. castaneus to $C$. pennsylvanicus detected on the basis of the symbiont dendrogram is neither supported by the phylogenetic analysis of the COI DNA sequences nor by morphological criteria (Creighton, 1950). Additionally, $C$. herculeanus and $C$. ligniperdus are clearly the closest relatives of $C$. pennsylvanicus and, in fact, they form a clade in the COI tree (bootstrap value $96 \%$ ). Currently, we do not have an explanation for this discrepancy. C. castaneus and $C$. pennsylvanicus populations show extensive overlap in geographic range. Whether this indicates an exceptional event of a horizontal transmission of the symbionts is difficult to evaluate and must await further analysis in the future.

The phylogenetic depth of the cluster of the ant symbionts is as high as that of the symbionts of different tsetse fly species and different families of aphids. It is therefore possible that, as suggested also for the Buchnera/aphid association, symbiosis may have been an original trait present already in a common ancestor of the ants living more than 100 million years ago. On the other hand, so far the symbionts have been detected only in the ant subfamily Formicinae, but not in species of the ancestral subfamilies Nothomyrmeciinae, Myrmeciinae and Ponerinae. The careful analysis of ancestral ant lineages will provide insights in the age of this symbiosis in the future. Interestingly, the phylogenetic tree based on the $16 \mathrm{~S}$ rDNA sequences also implies that the ant and aphid symbionts have a common ancestor. In many ecosystems ants and aphids are closely associated in beneficial symbiosis. In this context it is also noteworthy, that in contrast to free living Enterobacteriaceae and the symbionts of the tsetse flies, the ant and aphid symbionts both have unlinked 16S and $23 \mathrm{~S}$ rRNA genes. The disruption of rRNA operons is a feature observed also in other intracellular bacteria of unrelated phylogenetic lineages such as the rickettsiae. Such a scrambled gene organization appears to be correlated with genome reduction, which is a typical feature of many obligate intracellular bacteria (Andersson \& Kurland, 1998).

The extension of two helical regions by putative IVSs characterizes the $16 \mathrm{~S}$ rDNA of all symbionts of Camponotus species. The shortest variations are detected in the $C$. socius symbiont which also exhibits a higher $\mathrm{G}+\mathrm{C}$ content. These features correlate with the isolated position of this organism in the phylogenetic trees (Fig. 1). The length and $\mathrm{G}+\mathrm{C}$ content differ among members of the individual 16S rDNA subclusters and do not allow affiliation of symbionts to these clusters on the basis of properties of the IVSs.

The phylogenetic distances between individual ant endosymbionts are in many cases larger than those found between various genera of Enterobacteriaceae, indicating that they may form different genera by themselves. However, as no sequence data of other genes from the ant symbionts are available, it is 
possible that the substitution rate of the $16 \mathrm{~S}$ rDNA sequences of the ant endosymbionts is higher than the normal isochronic substitution rate. In fact, recent data demonstrate that in endosymbiotic bacteria with a long history of maternal transmission destabilizing base substitutions accumulate in their 16S RNA genes (Lambert \& Moran, 1998) and their coding genes show an excess of nucleotide substitutions causing amino acid replacements (Moran, 1996). In the case of the aphid symbionts the rate of $16 \mathrm{~S}$ RNA evolutionary change was estimated to be about twice that of freeliving bacteria and about 36-times greater than in homologous regions of the host 18S RNA (Moran, 1996; Moran et al., 1995).

The maternal transmission route of the symbiotic bacteria is in line with the fact that they are also found in the cytoplasm of the oocytes (Schröder et al., 1996), which distinguishes the ant symbionts from other intracellular endosymbionts such as those of the tsetse flies which could not be detected in the oocytes (Aksoy et al., 1997). In fact, there is increasing evidence that the bacterial invasion of the oocytes of the ants is the basis for the maternal transmission of the bacteria, because the symbionts can be detected in the endoderm forming the mid-gut epithelium very early during embryogenesis (C. Sauer, B. Hölldobler \& R. Gross, unpublished results). In oviparous aphids, the bacteria are endocytosed by the ovum and occur as a 'symbiont ball' at the posterior pole of the egg. In viviparous aphids, the mycetocytes are found in close proximity to the aphid embryos and the bacteria are able to enter the blastocoel of young embryos. Finally, they are also endocytosed by the mycetocytes of the embryos (Baumann et al., 1995; Buchner, 1965; Hinde, 1971). In this respect it may be interesting to note, that in contrast to the ant symbionts, which are found free in the mycetocyte cytoplasm, Buchnera is located in vacuoles within the mycetocytes, but not free in the cytoplasm. The transmission routes of Wigglesworthia in the tsetse flies remains obscure, because they are neither found in the ovaries nor in milk glands of their host organisms (Aksoy et al., 1997). Therefore, despite several similar features of the various mycetocyte bacteria, there are substantial differences in their dissemination strategies which may reflect different origins or adaptation to their host's biology.

According to Murray \& Schleifer (1994) the properties of uncultured organisms should be recorded by a 'Candidatus' designation. Therefore, we propose for the Camponotus symbionts the designation 'Candidatus Blochmannia' (Bloch.man'ni.a' N.L. fem. n. referring to F. Blochmann, a German zoologist who provided the first description of the endosymbiotic bacteria in ants as early as 1887). 'Candidatus Blochmannia' comprises Gram-negative rod-shaped bacteria which are found in the cytoplasm of specialized cells, so-called mycetocytes, intercalated between midgut epithelial cells or in oocytes of ants of the subfamily Formicinae. Bacterial cells are non-sporulating and divide by septation. They are $0.5-1 \cdot 5 \mu \mathrm{m}$ in width and have a quite variable length between 12 and $30 \mu \mathrm{m}$. On the basis of the 16S rDNA sequences, these bacteria belong to the $\gamma$-subclass of the Proteobacteria. The 16S RNA encoding $r r s$ genes are not located upstream of the 23S RNA genes. Cospeciation with their host animals indicates that transmission of the bacteria generally occurs vertically. For the symbionts of the ant species $C$. floridanus, $C$. rufipes and C. ligniperdus the identification of unique regions within the $16 \mathrm{~S}$ rDNA allowed their unequivocal identification by in situ hybridization in their respective host organisms. On the basis of these unique sequences we propose the symbionts of these three species to be designated as follows.

'Candidatus Blochmannia floridanus' (flo'ri.da.nus. N.L. masc. adj.) [(Proteobacteria) NC; NAS (GenBank no. X92549), oligonucleotide sequence complementary to a unique region of the $16 \mathrm{~S}$ rRNA gene 5'-CTCTACTCAGTTCTTTGGG-3'; S (Camponotus floridanus, mycetocytes)] (Schröder et al., 1996).

'Candidatus Blochmannia rufipes' (ru.fi.pes. N.L. masc. adj.; C. rufipes is characterized by red legs) [(Proteobacteria) NC; NAS (GenBank no. X92552), oligonucleotide sequence complementary to a unique region of the 16S rRNA gene 5'-GTCTATGTAGTTCTTTGG-3'; S (Camponotus rufipes, mycetocytes)] (Schröder et al., 1996).

'Candidatus Blochmannia herculeanus' (her'cu. lea.nus. N.L. masc. adj.) [(Proteobacteria) NC; NAS (GenBank no. X92550), oligonucleotide sequence complementary to a unique region of the 16S rRNA gene 5'-GTGGGCTATTACCCCG-3'; S (Camponotus herculeanus, mycetocytes)] (Schröder et al., 1996).

\section{ACKNOWLEDGEMENTS}

The authors would like to thank Paul Baumann for helpful discussions, Dagmar Beier for critical reading of the manuscript, and Ulrike Steiner and Ina Kramer for skilful technical assistance. We also thank Nancy Moran and one anonymous reviewer for the very helpful comments. This work was supported by a Feodor-Lynen grant to J.G. and by the Deutsche Forschungsgemeinschaft (Gr1243/4-1 and SFB251) and the Fonds der Chemischen Industrie.

\section{REFERENCES}

Amann, R., Springer, N., Ludwig, W., Görtz, H. D. \& Schleifer, K. H. (1991). Identification in situ and phylogeny of uncultured bacterial endosymbionts, Nature 351, 161-164.

Amann, R., Ludwig, W. \& Schleifer, K. H. (1995). Phylogenetic identification and in situ detection of individual microbial cells without cultivation, Microbiol Rev 59, 143-169.

Andersson, S. G. E. \& Kurland, C. G. (1998). Reductive evolution of resident genomes, Trends Microbiol 6, 263-268.

Aksoy, S. (1995). Molecular analysis of the endosymbionts of tsetse flies: $16 \mathrm{~S}$ rDNA locus and overexpression of a chaperonin, Insect Mol Biol 4, 23-29. 
Aksoy, S., Chen, X. \& Hypsa, V. (1997). Phylogeny and potential transmission routes of midgut-associated endosymbionts of tsetse flies (Diptera: Glossinidae), Insect Mol Biol 6, 183-190.

Bandi, C., Sironi, M., Damiani, G., Magrassi, L., Nalepa, C. A., Laudani, U. \& Sacchi, L. (1995). The establishment of intracellular symbiosis in an ancestor of cockroaches and termites, Proc $R$ Soc Lond B 259, 293-299.

Baumann, P. \& Moran, N. A. (1997). Non-cultivable microorganisms from symbiotic associations of insects and other hosts, Antonie Leeuwenhoek 72, 39-48.

Baumann, P., Baumann, L., Lai, C.-Y., Rouhbakhsh, D., Moran, N. A. \& Clark, M. A. (1995). Genetics, physiology and evolutionary relationships of the genus Buchnera: intracellular symbionts of aphids, Annu Rev Microbiol 49, 55-94.

Baumann, P., Moran, N. A. \& Baumann, L. (1997). The evolution and genetics of aphid endosymbionts, BioScience 47, 12-20.

Blochmann, F. (1887). Über das Vorkommen bakterienähnlicher Gebilde in den Geweben und Eiern verschiedener Insekten, Zentbl Bakteriol 11, 234-240.

Bolton, B. (1996). A New General Catalogue of the Ants of the World. Cambridge, MA: Harvard University Press.

Buchner, P. (1965). Endosymbiosis of Animals with Plant Microorganisms. New York: Interscience.

Chen, X., Li, S. \& Aksoy, S. (1999). Concordant evolution of a symbiont with its host insect species: molecular phylogeny of genus Glossina and its bacteriome-associated endosymbiont, Wigglesworthia glossinidia, J Mol Evol 48, 49-58.

Cochran, D. G. (1985). Nitrogen excretion in cockroaches, Annu Rev Entomol 30, 29-49.

Creighton, W. S. (1950). The ants of North America, Bull Mus Comp Zool 104, 1-585.

Dasch, G. A., Weiss, E. \& Chang, K.-P. (1984). Endosymbiosis of insects. In Bergey's Manual of Systematic Bacteriology, Vol. 1, pp. 811-833. Edited by J. G. Holt \& N. R. Krieg. Baltimore, MD: Williams \& Wilkins.

De Soete, G. (1983). A least square algorithm for fitting additive trees to proximity data, Psychometrika 48, 621-626.

Douglas, A. E. (1989). Mycetocyte symbiosis in insects, Biol Rev Camb Philos Soc 64, 409-434.

Douglas, A. E. (1998). Nutritional interactions in insectmicrobial symbioses: aphids and their symbiotic bacteria, Annu Rev Entomol 43, 17-37.

Felsenstein, J. (1993). PHYLIP (Phylogeny Inference Package) version 3.5.1. Seattle: Department of Genetics, University of Washington.

Gadau, J., Brady, S. G. \& Ward, P. S. (1999). Systematics, distribution, and ecology of an endemic California Camponotus quercicola (Hymenoptera: Formicidae), Ann Entomol Soc Am 92, 514-522.

Heddi, A., Grenier, A. M., Khatchadourian, C., Charles, H. \& Nardon, P. (1999). Four intracellular genomes direct weevil biology: nuclear, mitochondrial, principal endosymbiont, and Wolbachia, Proc Natl Acad Sci USA 96, 6814-6819.

Hinde, R. (1971). The control of mycetocyte symbiotes of the aphids Brevicoryne brassicae, Myzus persicae and Macrosiphum rosae, J Insect Physiol 17, 1791-1800.
Hunt, G. J. \& Page, R. E., Jr (1994). Linkage analysis of sex determination in the honey bee (Apis mellifera), Mol Gen Genet 244, 512-518.

Jukes, T. H. \& Cantor, C. R. (1969). Evolution of protein molecules. In Mammalian Protein Metabolism, pp. 21-132. Edited by H. N. Munro. New York: Academic Press.

Kolb, G. (1959). Untersuchungen über die Kernverhältnisse und morphologischen Eigenschaften symbiontischer Mikroorganismen bei verschiedenen Insekten, Z Morphol Ökol Tiere 48, $1-71$.

Lambert, J. D. \& Moran, N. A. (1998). Deleterious mutations destabilize ribosomal RNA in endosymbiotic bacteria, Proc Natl Acad Sci USA 95, 4458-4462.

Maidak, B. L., Olsen, G. J., Larsen, N., Overbeek, R., McCaughey, M. J. \& Woese, C. R. (1997). The RDP (Ribosomal Database Project), Nucleic Acids Res 25, 109-111.

Moran, N. A. (1996). Accelerated evolution and Muller's ratchet in endosymbiotic bacteria, Proc Natl Acad Sci USA 93, 2873-2878.

Moran, N. A., Munson, M. A., Baumann, P. \& Ishikawa, H. (1993). A molecular clock in endosymbiotic bacteria is calibrated using the insect hosts, Proc R Soc Lond B 253, 167-171.

Moran, N. A., von Dohlen, C. D. \& Baumann, P. (1995). Faster evolutionary rates in endosymbiotic bacteria than in cospeciating insect hosts, $J$ Mol Evol 41, 727-731.

Murray, R. G. E. \& Schleifer, K. H. (1994). Taxonomic notes: a proposal for recording the properties of putative taxa of procaryotes, Int $J$ Syst Bacteriol 44, 174-176.

O’Neill, S. L., Giordano, R., Colbert, A. M. E., Karr, T. L. \& Robertson, H. M. (1992). 16S RNA phylogenetic analysis of the bacterial endosymbionts associated with cytoplasmic incompatibility in insects, Proc Natl Acad Sci USA 89, 2699-2702.

Nogge, G. (1982). Significance of symbionts for the maintenance of an optimal nutritional state for successful reproduction in hematophagous arthropods, Parasitology 82, 299-304.

Rainey, F. A., Ward-Rainey, N. L., Janssen, P. H., Hippe, H. \& Stackebrandt, E. (1996). Clostridium paradoxum DSM7308 ${ }^{\mathrm{T}}$ contains multiple 16S rRNA genes with heterogeneous intervening sequences, Microbiology 142, 2087-2095.

Rouhbakhsh, D. \& Baumann, P. (1995). Characterization of a putative 23S-5S rRNA operon of Buchnera aphidicola (endosymbiont of aphids) unlinked to the $16 \mathrm{~S}$ rRNA-encoding gene, Gene 155, 107-112.

Saitou, N. \& Nei, M. (1987). The neighbor-joining method: a new method for reconstructing phylogenetic trees, Mol Biol Evol 4, 406-425.

Sambrook, J., Fritsch, E. F. \& Maniatis, T. (1989). Molecular Cloning: a Laboratory Manual, 2nd edn. Cold Spring Harbor, NY : Cold Spring Harbor Laboratory.

Schröder, D., Deppisch, H., Obermayer, M., Krohne, G., Stackebrandt, E., Hölldobler, B., Goebel, W. \& Gross, R. (1996). Intracellular endosymbiontic bacteria of Camponotus species (carpenter ants): systematics, evolution and ultrastructural characterization, Mol Microbiol 21, 479-489.

Swofford, D. L. (1998). PAUP: phylogenetic analysis using parsimony (and other methods), version 4. Sunderland, MA: Sinauer. 